\title{
The Enemy Character of Merchant Ships
}

\section{Giovanni Alessandro Rosso}

To cite this article: Giovanni Alessandro Rosso (1916) The Enemy Character of Merchant Ships, Royal United Services Institution. Journal, 61:442, 367-374, DOI: 10.1080/03071841609419063

To link to this article: http://dx.doi.org/10.1080/03071841609419063

$$
\text { 曲 Published online: } 11 \text { Sep } 2009 .
$$

Submit your article to this journal

Цll Article views: 5

Q View related articles $匚$ 


\title{
THE ENEMY CHARACTER OF MERCHANT SHIPS.
}

\author{
The ABOLITION of ARTICLE 57 of the DECLARATION OF LONDON.
}

By Giovanni Alessandro Rosso.

(Translated by permission from the Rivisti Maritima,

by Assistant Paymaster P. S.MiLES, R.N.)

THE laws of naval war, the general principles of which seemed to have been standardized at the last international conference, have been modified in many important particulars during the progress of the present struggle. Some such result was inevitable, owing to the exceptional and unforeseen character of the conflict, its extent and violence, and the employment of new arms and methods of war.

At the beginning of hostilities it seemed as though the conduct of the war would be governed by the Declaration of London, and such was the unanimous desire of the belligerents : but the necessities of the conflict were the cause of successive modifications, especially as regards such questions as lists of absolute and conditional contraband, presumed knowledge of a state of blockade, destination of neutral merchant vessels, etc., etc. Considering the complicated nature and wide extent of the operations of modern commercial warfare, the employment of submarines, and the importance of the pressure exercised by the blockade in obtaining a decision, it seems by no means strange that some such modifications should have been rendered necessary, -and that besides the affirmation of principles new to International Law, doctrines (c.g., the proclamation of parts of the open sea as "military areas"), long since considered out of date, should have been revived. Germany, to whose interests it was to maintain intact the principles embodied in the Declaration of London, ?.as herself forced to make some modifications in them (e.g., the declaration of wood as contraband of war), and Dernburg, one of her best-known public men, recently admitted that the belligerents were justified in their changed attitude towards laws formerly accepted as binding.

Without probing too deeply into the origins and consequences of this phenomenon, the main reason can be found in the fact that pressure on sea-borne traffic, which was formerly considered as subsidiary to purely military operations, has now become one of the primary weapons in the conflict. In former wars the capture of merchant shipping and the limitation of navigation and commerce were merely auxiliaries to the operations of larger scope entrusted to the armed forces, but under present circumstances the enforcement of a strict blockade and the annihilation of the enemy's mercantile marine are the only means at our disposal for bringing about a definite decision. 
The whole system of laws, constructed with infinite care and labour to regulate the conduct of war at sea, has had to accommodate itself to this imperious necessity, and it will have again to yield if the supreme needs of the country call for further restrictions on national and individual liberty. The latest, in order of time, of the modifications referred to is the abrogation, announced by the British Government in the Order in Council of October 26th, 1915, of Article 57 of the Declaration of. London, which reads as follows :-

"Subject to the provisions respecting transfer to another "flag, the neutral or enemy character of a vessel is determined. "by the flag which she is entitled to fly.

"The case where a neutral vessel is engaged in a trade "which is closed in time of peace remains outside the scope of, " and is in no wise affected by this rule."

This act of England's has passed almost unobserved, although it represents, beyond all doubt, the most important decison as regards International Naritime Law adopted during the present conflict: important, as will be seen, both in its actual significance and in its consequences.

The Declaration of Paris of 1856 , with its well-known formula, "The flag covers the goods," solved, theoretically, the greatest problem of the freedom of the seas, but in practice the determination of whether ships and goods were enemy or neutral was left to the arbitrary interpretation of the different States. The opinion held naturally varies according to whether it is the interests of belligerents or neutrals that are at stake. The latter obviously favour a narrow view of what constitutes an enemy, so as to be able to take over a large part of the trade of the warring States, while the former, on the contrary, press for a wider application of the term, which will perr.it them to stifle all the enemy's attempts at commercial activity under the protection of a neutral flag.

These tendencies had their birth in two fundamental theories, which bore the names of France and England respectively. In one point they agreed-viz., that ships flying an enemy flag were hostile and liable to capture-and the justification for such a rule is evident. The diversity between the two systems arose in their treatment of ships flying a neutral flag.

The French considered as neutral every ship which had a right to fly a neutral flag, independently of the nationality of the owners or of those who had claims upon the vessel. An exception was only made (Edict of July, 1878 ) in the case of ships which had been transferred to another flag after the outbreak of war.

The English doctrine did not accept the evidence of the flag as final: enquiry was always made into the nationality of the vessel's owners. An enemy was defined as any person domiciled in a hostile country, since, with sound common-sense, the British Courts considered the economic tie indicated by the domicile of an individual as of more importance than his nationality.

At the 1908 Naval Conference at London, the traditional British theory, shared by America, was held also by Japan; while the French 
theory was supported by the continental powers-amongst others, Germany, Russia, Italy, and Holland. Great Britain, however, came to the Conference after a bitter experience in the Russo-Japanese War, when she was made to feel all the burdens of neutrality. She announced therefore that her theory and practice as regards maritime law had grown up during a period (second half of 18 th century to second half of Igth) in which she was almost always at war, and had naturally served rather the interests of a belligerent than those of a neutral. When she found herself differently situated she had felt the disadvantages under which a commercial neutral laboured, and was willing to make concessions. In Sir Edward Grey's instructions to the British delegates to the Conference, this view is explicitly stated with reference to the enemy character of merchant vessels.

As their most powerful opponent had yielded, the views of the continental powers prevailed, and Article 57 of the Declaration of London was the result. This, without prejudice to the regulations as to the transfer of flag, laid down definitely that " the enemy or neutral character of a vessel is determined by the flag which she has a right to fly."

The full effect of this statement must be briefly examined. There could be no doubt that it constituted a victory for the neutrals, since it freed them from all fear of being compromised by the part ownership of enemy citizens, and ftom any uncertainty, which was all against their interests, as to when a ship might be considered hostile. The simple and explicit words of the Article eliminated the subordinate questions of the nationality or domicile of the owners, although subsequent enquiries might always be made as to whether the ship was legally authorized to fly a neutral flag.

The rule was based on the guarantee, expressed in the laws of all the larger States, that for a ship to have a right to the flag of a cou stry she must be owned entirely or for the greater part by citizens of the country to which the flag belongs. The right to the flag was, therefore, as Renault affirmed in his explanatory speech to the Conference, the most certain proof that the ship is really a unit of the mercantile marine of a country, and, consequently, the best guide in determining whether she is neutral or hostile.

The essential value of Article 57 consequently lay in its limitation of the powers granted to belligerents; it tended to lessen the effects of hostile action by eliminating the possibility of direct pressure on neutral commerce.

Her experience in the present war has convinced Great Britain of the insufficiency of the guarantee on which Article 57 was based, and has shown that the principles which inspired it served rather as an incentive to fraud on behalf of the belligerents than as a protection to neutral interests.

Constant mention was made in the great English dailies of the various means by which Germany was evading the blockade. For example, attention was directed to the case of a certain Herr Jensen, living at Copenhagen, who had entered in the United States Maritime Register, under the name of Mr. Richard Wagner, eight ships, some 
of which had been bought from Germans and all purchased with German money.

Jensen was imprisoned some time later by the Danish authorities for smuggling, but others after him continued the work. The Times announced that many such ships bound with cargo to Denmark were captured by the Germans, who, after having unloaded them, released them for the process to be repeated.

Some time later, on the occasion of the seizing by the British of the s.s. "Hocking," flying the American flag, the Washington correspondent of the Morning Post declared that he had been informed that that ship, and many others which had recently become the property of the American Transatlantic Company of New York, had been entered in the American Register with the sole idea of avoiding capture, and there was nothing American about them but the name, their real proprietor being a certain Hugo Stinnes, who lived at Mulheim.

It is certain, in any case, that the British Government was under no illusions as to the frequency with which the German blockade was violated, through the complacency shown by reutral States in allowing the entry in their registers of ships which were still foreign or, more precisely, German property. Great Britain has now, in the Order in Council of October 26th, 1915, abrogated Article 57 of the Declaration of London, and fallen back on the old Anglo-American rule, which, to put the matter shortly, applies to ships the same principles as the Declaration of London does to goods, i.e., enquiry is made into the character of the owner, and any enemy goods are sold on behalf of the Crown or the neutral co-proprietors.

One of the earliest applications of this rule, as regards enemy shares in a vessel, was in the case of the "Vrouw Elizabeth" (1803), and, as regards enemy interests in mortgages or liens upon the ship, the cases of the "Tobago" (I804) and "Mlarianna" (1805).

The rule is closely bound up with another most important question, one which the Conference of London did not succeed in settling, or rather could only decide in part, that is, should nationality or domicile be the deciding factor in determining the neutral or enemy character of an owner, and under what circumstances is the transfer of flag valid?

The flying of a neutral flag merely constitutes a presumption in favour of a ship, and, if it can be shown, as an offset to this, that the proprietors of the vessel are enemy, Great Britain will be ruled by their place of domicile in determining their character. The continental theory, following the principle of nationality, considered only the case of those who were de jure enemies, owing to the fact that they belonged to a hostile State; the advocates of the Anglo-American theory, on the contrary, looking at the matter from the traditional "common-sense" point of view of their courts of justice, strove rather to ascertain whether an individual was an enemy de facto, that is, was he domiciled in hostile territory, and, if so, was there any economic bond between him and the enemy. As usual, one theory served the interests of the neutrals, while the other favoured the belligerents.

At London, as has been said, the rivalry between the continental system, to which, besides France, Italy, Russia, and, in most points, 
Austria adhered, and the English, advocated also by Japan, Holland, and Spain, was shown in its full force when the question of the enemy or neutral character of goods was under consideration. Germany, through her representative, Kriege, proposed a compromise; the adoption, that is to say, of a decision according to the nationality of the person who bears the risk of any loss during the voyage. But since the acceptance of this principle would have led to great complexity of procedure and a most detailed examination of foreign laws, so as to ascertain who should in reality be considered the " porteur des risques," it was not adopted. There were sound reasons against making the consignee bear the risk, as this would be to confine the war on commerce exclusively to goods imported by an enemy direct, and open a loophole for frauds through neutral consignees; nor could the consignor justly bear it, as that rule would be open to similar objections, though in the opposite direction, nor finally could it be left to the discretion of the belligerent to adopt one system or the other, as opportunity would be given for an unlimited possibility of rulings harmful to neutrals. The Conference, therefore, decided to leave. it to the discretion of each State whether she would adopt the standard of nationality or that of domicile in determining the enemy or neutral character of the owner of the goods; and, to-day, when Article 57 is no longer in force, the same latitude is allowed with regard to the ownership of vessels, one of the immediate consequences being that neutral commerce is exposed to increased risks.

It is not enough to say that the British Prize Courts adhere to the criterion of domicile in determining whether the owner's interests are coincident with those of the enemy. The Court possesses almost unlimited discretion in deciding what is to be considered the domicile. Luckily, however, a man can only have one domicile, though he can have a dual nationality, but how is his domicile to be ascertained?

English law has always regarded two points as fundamental-the object and the duration of the domicile in enemy territory. Above all, the intention of settlement is decisive in determining the domicile, but it is rarely possible to prove an intention in a case where it is to a person's interest to conceal it, so that the decision of the Court is necessarily based on presumption and internal evidence. If a neutral citizen resides in a foreign country for permanent commercial reasons, and his stay there is prolonged beyond a certain period, the presumption is evident that, even without his expressing a desire to that effect, that country must be considered as his domicile, because that bond of economic interest is created at which Great Britain, with sound commonsense, has always sought to strike. The English Courts thus arrogate to themselves very wide powers, subject to no definite rules, and only limited by the good faith and knowledge of the judges. Lord Stowell himself has drawn attention to the gradual process by which the fortuitous residence of a citizen in a foreign country grows little by little into presumptive evidence of his domicile; but, though making clear that no rule could a priori fix the duration of time necessary for the purpose of domicile, he lays stress on the wide discretionary powers entrusted to the Courts by English Prize Law. 
These discretionary powers are yet more evident in the execution of duty which is laid upon the Court after determining the place of domicile-that of deciding whether it is really situated in enemy territory, since this must, of course, be considered in trying the case.

It is obvious that there can be no-difficulty in settling the matter when the territory; properly so called, of an adversary is in question, but trouble inevitably arises in dealing with lands conquered or abandoned by the enemy. English law invariably adopts the standpoint of actual rather than legal community of interests, and makes a point of considering as friendly territory conquered from an enemy, while that which has fallen into an adversary's hands is judged to be hostile.

For the same reason a mere change of sovereignty is not considered sufficient, for example, where this is the result of a treaty and actual possession of the ceded territory has not been taken; vice versâ, the mere fact of enemy occupation of a State is sufficient to invest it with a hostile character, even if the occupation has never been legally sanctioned.

English law is less explicit with regard to countries which the enemy has temporarily occupied, without any intention of annexation, but solely for strategical reasons. Other difficulties arise in the case of States where insurrections have broken out, or which (like Cyprus and Egypt before the recent annexations) owe a rominal dependence to powers other than those which are in actual occupation. In such instances the ruling of the Court is based on the actual circumstances of each case, and investigation is made into whether the interests of such countries are in consonance with their legal status. In the same way, in places where Capitulations are in force, individuals are considered to bear the nationality of the foreign consul who protects their interests.

The British Courts do not, however, disregard the fact that nationality is a subsidiary proof, as it always constitutes a presumption favourable or the reverse to the individual. It acquires its full value in cases of change of domicile, where an individual, by breaking the economic bonds which unite him to the enemy, loses, ipso facto, the reason for his hostile character, and in this connection the bare intention of a. change of residence is sufficient, whenever it may have been manifested.

The other point which is brought into prominence by the abrogation of Article 57 is that of the legitimacy of transfer of flag. This is especially the case in the present conflict, when Great Britain has every opportunity of attacking German interests in the steamers sold by that State in such large numbers to America. This difficult question was, as is well known, the theme of active diplomatic negotiations between England and the United States, before the issue of the Order in Council of October 26th. From the legal point of view, since it is only Article 57 that has been abrogrted, and there has been no modification to the other articles which Dear on the question of transfer of flag, it seems evident that Great Britain intends to adhere to the provisions of the articles which remain in force, instead of to her own 
laws and practice in the matter; these, however, as we have seen, apply when the domicile is in question.

The English system seemed primâ facie more liberal than the continental, as the sale of ships after the outbreak of hostilities was not absolutely prohibited, although the bonâ fides of each case had to be proved. The transfer of ships in transitu, i.e., during the voyage, was forbidden. For this reason the bill of sale, complete and drawn up in proper legal form, and so worded as to eliminate the possibility of fraud, was always required to be carried on board, and it was necessary for the bona fide character of the sale to be confirmed by the service on which the ship was employed after the transfer had taken place. Under this system the examination of the Court extended over so many points that the liberal principle was transformed in practice into a rule more rigorous than the French, which, without more ado, refused to recognize any transfer which had taken place after the outbreak of war.

The principle adopted by the Declaration of London, after agreement had been reached by long argument between the representatives of the various powers, was based on a compromise between the English and continental systems. A transfer which takes place before the outbreak of hostilities is presumed to be valid, though the presumption may be negatived by the showing of the captor that it was not made in good faith, but only with the object of avoiding the risks to which an enemy vessel is exposed. A transfer completed after the outbreak of war gives rise to the contrary presumption, which, in its turn, may be contested by a purchaser who can prove that he acted in good faith.

In the first case there is a presumption, if the bill of sale is not on board a vessel which lost her belligerent nationality less than 60 days before the outbreak of hostilities, that the transfer is void: when the transfer took place more than 30 days before the commencement of hostilities, there is a presumption that it is valid if it is unconditional, complete and in conformity with the laws of the countries concerned, and if its effect is such that neither the control of, nor the profits arising from the employment of, the vessel remain in the same hands as before the transfer.

In the second case the unfavourable assumption holds good if the transfer was effected in transitu or in a blockaded port, if there is any possibility of a re-sale, or if the requirements of the municipal law, governing the right to fly the flag under which the vessel is sailing, have not been fulfilled.

The English Courts ought therefore to be guided by these principles in conducting the enquiries assigned to them after the abrogation of Article 57, but the system bears hardly on the neutrals, and is likely to increase yet more the grave uncertainty caused by the wide discretionary powers, of which mention has been made above, exercised in determining the place of domicile.

There was no delay in applying the new regulations introduced by the Order in Council of October zerih, 1915. On October 3oth and November Ist respectively, the s.s. "Hamborn" (Dutch) and s.s.

VOL. LXI. 
"Hocking" (American) were seized for suspected German ownership and taken to Halifax to await the decision of the Prize Court.

The adoption of this practice will evidently have material effect on the strictness of the blockade, and neutrals, as well as Germans, will be the losers. The right of capture has no longer any well-defined limits, and the safety of the goods also, for which a neutral flag is no longer an absolute guarantee, is often compromised.

However, the British Government cannot be condemned for its action. The old Anglo-American rule, confirmed by ancient legal practice, has an undeniable basis of equity, because it is considered quite legitimate to practise fraud upon the laws which a State has imposed in the lawful exercise of her powers as a belligerent. Errors may, however, arise, if this principle is carried to its extreme limits.

It must be remembered that this repudiation of rules, already accepted and embodied in an international agreement, has been brought about by a reaction of feeling and the exceptional features and necessities of the present war. For the first time in history the neutrals form but a small minority as opposed to the belligerent parties, and their interests are but trifling in comparison with those which the combatant powers have at stake. For the first time pressure on sea-borne commerce has become a primary operation in the waging of war, and no longer occupies a secondary place to the action of the armed forces of the country. For the first time there have appeared methods of warfare, ruses and fraudulent stratagems up to now unknown, and which could not have been foreseen, to combat which all our forces are needed.

It is not to be wondered at that some, relatively few indeed, of the elaborate regulations drawn up at the Hague and London, after peaceful theoretical discussion by men who could not contemplate the present state of affairs, should have proved unfitted to bear contact with such a difficult and novel situation.

It would not be right, however, to deduce that the laws of maritime war are too fragile to be of any value or utility except from a scientific point of view, instead, they will have to constitute the basis of discussion for the national representatives who, in the future, will frame a new code of laws, and will form a monument to the necessity of paying more attention to practical considerations and the exigencies of modern warfare, and less to humanitarian chimeras impossible of realization. 